\title{
SOME ORIENTAL NEUROPTEROID INSECTS
}

\author{
By NATHAN BANKS
}

Museum of Comparative Zoology, Cambridge, Mass.

Most of the species described below are from the Philippines, collected some years ago by the late C. F. Baker. Besides the new species there are descriptions of the curious Acanthaclisid (Madrasta), the only one known from the Malayan Islands, and of what I consider both sexes of an Osmylid recently published as new by Mr. Petersen from Ceylon. The types of the new species are deposited in the Museum of Comparative Zoology.

\section{Psocidae}

\section{Hageniella pusilla sp. nov.}

Body pale yellowish, head and notum with scattered short white hair; antennæ pale, with long gray hairs; legs pale. Wings hyaline; veins brownish. Beyond basal fifth of wing is a broad black band extending out to the areola postica and occupying half of stigma; end of anal vein and base of stigma with a black spot.

Radius and medius touching at one point, fork of radius about as far back as first fork of medius; areola postica scarcely twice as long as broad; fork of radius about equal to its stem.

\section{Length $2.2 \mathrm{~mm}$.}

From Mt. Makeling, Philippine Islands (Baker).

The dark band across fore wing reminds one of $H$. zonatus, but in that species (which is much larger) the band is not one-third as broad, and paler; the areola postica longer, radial stem longer than fork, etc. 
Psyche, 1931.

Vol. 38, Plate 5.

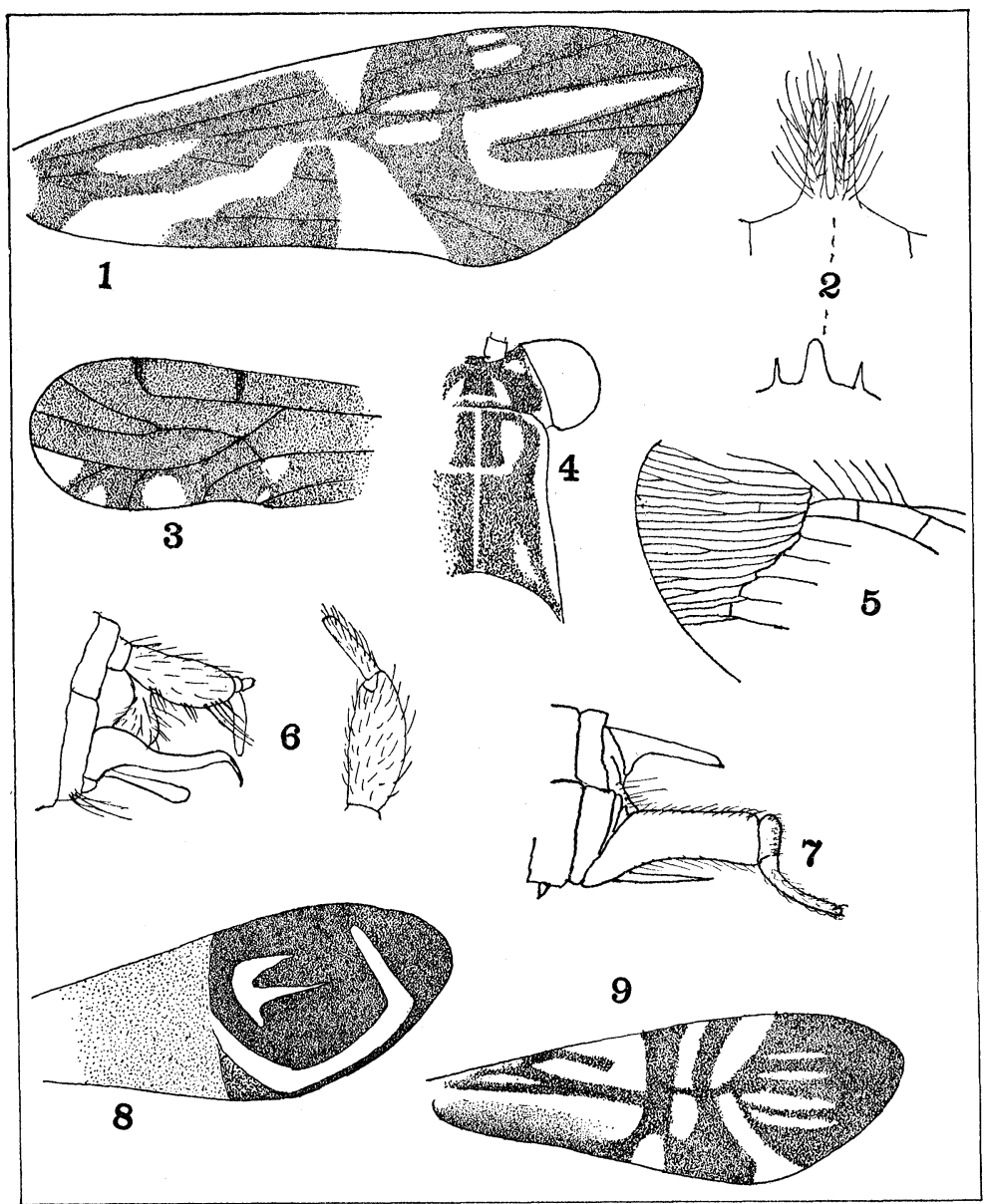

Banks, Neuropteroid Insects. 
Tagalopsocus hyalinus sp. nov.

Head yellowish brown, clothed with short white hair, thoracic notum darker (but not black), with still shorter white hair; antennæ pale, with moderately long hair; abdomen dark; legs pale.

Wings hyaline, veins yellowish brown, margin all around brown as in T. luzonensis, the margins and veins with many short hairs as in that species, the stigma is a little wider in the middle, and without the dark color of T. luzonensis, the stem of the radial fork is a little curved, and the veins of fork also more curved than in the other species, and lower branches of media also slightly curved. The areola postica is large and high as in that species.

Length 4.5 to $5 \mathrm{~mm}$.

From Imugin, N. Viscaya; Surigao, Mindinao, Mt. Makeling, Luzon, Philippine Islands (Baker).

Ectopsocus aethiops var. bakeri var. nov.

Fig. 3.

This agrees with $E$. aethiops Hagen in the position of the pale marks, three along median cells, and one above anal vein. In this form the first and last of those in median cells are very large, and that above end of anal vein a good-sized, triangular spot; in the typical aethiops (Ceylon) the three along median cells are all very small and subequal, and that above end of anal vein reduced to a line.

of the same size as typical form.

From Mt. Makeling, Philippines (Baker).

\section{MYRMELEONID $A E$}

Stenares frazeri sp. nov.

\& Face pale, cheeks wth an inner dark streak next to the clypeus, mandibles and palpi dark, a dark band through bases of the antennae; vertex pale, with a median triangular black spot from behind and numerous (about 40) 
small scattered dots; pronotum pale, a broad, median black stripe, broadened in middle, a lateral black mark, narrow in front, very broad behind, and in front of this, each side, a dark dot; rest of the notum pale, with median dark stripe, and shorter, narrower lateral stripes; legs dark reddish brown at base, nearly black at tip; abdomen dark, darkest at tip, above toward base mottled with pale.

Hair on thorax long, mostly white or gray, some brown in middle and on sides of notum, pleura with some brownish hair below, abdomen with long white hair at base, beyond with extremely short white appressed hair, some at tip dark; legs with short appressed white hair, and longer black bristles. Labial palpi elongate, last joint about as long as front femur; vertex much elevated, very slightly bilobed; pronotum more than twice as broad as long. Legs short, spurs equal two joints, four tarsal joints short nearly subequal, fifth equal others together. Wings long, rather blunt-pointed, much marked with small dark dots, marks much as in S. improbus but the stigmal spot broken up; hind wings also marked in front and behind much as in $S$. improbus, near hind margin a more or less broken streak; there is no trace of the three large spots in the middle area of $S$. improbus. The venation is like that of $S$. improbus except that the costal area of the hind wings is simple for about one-half its length.

Length of fore wing $67 \mathrm{~mm}$., width $16 \mathrm{~mm}$. Length of hind wing $63 \mathrm{~mm}$. , width $15 \mathrm{~mm}$.

From Coorg, India, May (Major Frazar).

The several specimens of S. improbus that I have seen, as well as the type have the three large spots in the hind wing very distinct.

Nesoleon perpunctatus sp. nov.

Face yellowish, a black spot on clypeus, and the labrum mostly black, a black interantennal mark reaching below the antennæ and above extending up in front of vertex, 
and continued back over the vertex as a median stripe; palpi pale; antennæ deep black; pronotum pale, with rather broad median black stripe and narrower lateral stripes remote from the margin and interrupted near front end; these three stripes are continued back over the rest of the notum, with a few additional short streaks, the scutelli with broad black stripe; pleura pale, with some black marks mostly on lower part; legs pale, femora dotted and the hind-tibia lined with dark; venter of abdomen black, above pale, with median dark stripe. Fore wings rather densely marked with many dark spots of about one size, nearly always at the junction of veins, but none on the banksian line; hind wings with many similar spots, mostly in the apical area and near posterior margin; stigma in both pairs large, distinct, pale yellowish. In both wings ten cross-veins before radial sector, latter with twelve or thirteen branches, in fore wings one of them looks like a separate radial sector; nine branches of first anal in fore wing, seven in hind wing; in both wings radial sector much beyond the cubital fork.

Length fore wing $34 \mathrm{~mm}$., width $11.5 \mathrm{~mm}$.

Length hind wing $29 \mathrm{~mm}$., width $9 \mathrm{~mm}$.

From Nandapur, Madras Prov., India, 27 October (Major Frazar).

Eophanes gen. nov.

In the fore wing the second anal vein runs close up to the first anal and then turns down and unites with the third anal for some distance; in hind wing but one cross-vein before the radial sector. The legs are slender, the femora cylindric, the front femora more than twice as long as the coxæ; at base of hind wing is a short vein closely parallel to hind margin and running into the branch of the second anal. In the fore wing the radial sector arises beyond the cubital fork; the claws are very long as in Paraglenurus. It differs from that genus in having the wings very much 
broader, and in having the spurs equal to four tarsal joints.

Type: $E$. formosa n. sp.

To this genus probably belongs the Formicaleo schladeri of Van der Weele. The wings are much as in his figure, but the hind ones more acute at tip and outer margin concave. The marks of the vertex and pronotum are very different from his figure.

\section{Eophanes formosa sp. nov.}

Fig. 4.

Interantennal mark black, extending a little below antennæ and above reaching up on vertex, leaving a yellow spot each side between antennæ and eyes; vertex with a yellow spot each side, and two toward middle behind; antennæ rather pale, tip dark. Pronotum with lateral margins and a fine median line pale, two pale spots in front, and two smaller ones behind; rest of notum mostly dark, but with several pale spots, two on the anterior lobe, and each side on the scutelli; pleura mostly dark, a few pale spots. Legs pale, femora and tibiæ dark at tips, and the tibiæ also toward the base, tarsi dark at tips of joints, spines and bristles black; abdomen dark, apex of first and middle and apex of second segment pale above, hair short, black. Wings with venation black, with patches of yellowish ones, the subcosta with about three times as many dark spots as on the radius; stigma whitish, many veinlets in apical field pale, and in certain lights a white spot (larger than stigma) before apex; the apical forks are dark, and near rhegma are a number of dark veins tending to make a cloud. The hind wing is similar, but the cloud at rhegma is larger, almost reaching the margin, and there is another cloud beyond it; the subapical white spot is present as in fore wing.

Antennæ as long as head and thorax; the pronotum longer than broad. In the fore wings the radial sector arises a little beyond the cubital fork, seven cross-veins before the sector, twelve branches to the sector; in hind 
wing the radial sector arises far before the cubital fork.

Length front wing $43 \mathrm{~mm}$., width $13 \mathrm{~mm}$.; length hind wing $43 \mathrm{~mm}$., width $10 \mathrm{~mm}$., abdomen $25 \mathrm{~mm}$.

From Mt. Makeling, Luzon, Philippines (Baker).

\section{Syngenes palpalis sp. nov.}

Greatly resembling S. longicornis in structure and markings; the dark of vertex not connected to the interantennal mark, the lateral dark stripe of the pronotum shows less tendency to be double; the dorsum of abdomen with five bright yellow V-marks, the last two segments with median dark stripe and lateral marginal stripes. The labial palpi are much longer than in S. longicornis, the last joint twice as long as the last joint of the maxillary palpi (in S. longicornis but little longer). The wings are practically the same as in the African species, but the hind wings are rather broader.

Length fore wing $48 \mathrm{~mm}$., width $12.5 \mathrm{~mm}$.; length hind wing $43 \mathrm{~mm}$., width $11.5 \mathrm{~mm}$.

From Vizagapakan, Madras Prov., India (Major Frazar).

\section{Madrasta handlirschi Navas}

Fig. 5.

Face rather bright yellow, above antennæ and the vertex dull black, palpi and basal joint of antennæ yellowish; pronotum black, a faint median pale line, two spots each side in front, a spot each side on middle lobe, and a submedian pair at base, and the posterior outer edge pale; rest of notum mostly black, some small pale spots; pleura largely pale, a few dark streaks; abdomen black, pale on base below; legs mostly pale, front femora dark in middle, tibiæ with two spots near middle and sometimes at tip. Hair of body very long, mostly white, some dark, mostly on face, and middle of pronotum; hair on the abdomen short, appressed, except some long hair below near base each side. Labial palpi very long, last joint longer than space between eyes (much longer than in occitana). Body stout; 
legs stout, spurs curved; male appendages short, slightly divergent, no longer than height of last segment, the latter much higher than long.

Wings broad toward tip as in $A$. fundata, marked much as in A. occitana; with scattered patches of white veins, and small dark spots; the subcosta and radius are dotted as well as spotted, above the origin of the radial sector there is a deep black spot between radius and subcosta, no spots along cubitus, one at base of pale stigma, also in the hind wing, latter not marked except veins partly pale. Costal area with two series of cells almost to base, nine to ten cross-veins before radial sector in fore wings, five in hind wings, nine branches to radial sector, cubitals not connected, banksian lines distinct, second and third anals united for short distance, then the third forked and connected once back to the second.

In the hind wings there is a remarkable structure at the apex of wing; the appearance is that the radius is suddenly turned backward in a curve. This is due to a bending down of the surface, and to the several small cross-veins being in one line, and the veinlets forked at this place, so that beyond, there are twice as many veinlets as usual.

Fore wing $52 \mathrm{~mm}$., hind wing $46 \mathrm{~mm}$., fore wing at stigma $12 \mathrm{~mm}$. broad.

From Baguio, Benquet, Philippines (Baker): Navas has evidently misspelled his locality, obviously intended for Mindoro.

\section{ASCALAPHID $2 E$}

\section{Suhpalacsa reducta $\mathrm{sp}$. nov.}

Face black, yellowish each side near the eyes; clypeus and labrum pale; face clothed with gray hair on lower part, dark above; vertex black, with dark hair; antennæ faintly annulate with pale on bases of joints; thorax above dull grayish black, with much dark and some pale hair; pleura gray, with long white hair; legs black, but rather paler on base, some long white hair on femora, spurs about equal to first tarsal joint; abdomen dull black, last 
segments with black hair. Wings hyaline, the stigma black, nearly as long as broad; venation dark brown to black; hind wings much shorter than fore pair, and scarcely broadened on the basal part; apical field with two rows of cells; in fore wing four cross-veins before radial sector, in hind wing but two, and the radial sector arises about even with the fork of cubitus ; in both pairs but four crossveins before cubital fork; five branches of radial sector; the first anal does not run into cubital fork, but bends down to margin; in hind wings the cubital area has but two rows of cells, in the fore wing the cubital area has two to four rows of cells, irregular in arrangement.

Length of fore wing 29 to $32 \mathrm{~mm}$., length of hind wing 23 to $25 \mathrm{~mm}$.

From Philippines, Mt. Makeling, Luzon, Island of Samar, and Suerno Mts., Negros.

By its dark face, black legs, wholly dark thorax, twocelled apical field, and open venation, particularly but two cross-veins before radial sector in hind wing, it is separated from all described species.

\section{CHRYSOPIDAE}

Chrysopa obliquata sp. nov.

Pale yellowish; face, vertex, and antennæ unmarked, but each side on vertex close to the eye is a narrow red stripe. Pronotum rather darker on sides than in middle, rest of thorax and legs pale; abdomen discolored. Wings hyaline, venation pale, gradates brown, ends of radial cross-veins and a few others partly dark, stigma whitish in both wings, elongate. In hind wing venation pale, but the ends of marginal forks on the outer hind margin are dark. Cubital cells slender, the second scarcely swollen above, divisory veinlet ends on the cross-vein above; gradate veinlets eight and nine, first series curved, nearer to radial sector than to the second series; in hind wings the rows more nearly parallel; in both wings there is a remarkable peculiarity in the outer radial cross-veins, those on basal part are straight across as usual but beyond middle they become 
very oblique and sinuous, and consequently the radial sector does not bend up so near to the radius as in other species.

Length of fore wing $15 \mathrm{~mm}$., width $5.5 \mathrm{~mm}$.

From Bagio, Benguet, Philippines (Baker).

\section{Spilosmylus ceylonensis Petersen}

Petersen described the male; I have both sexes of what appears to be this species, and give the description of the female.

\& Black; vertex with some red brown marks above; antennæ pale, basal joints dark; on pronotum and also mesonotum are small sharp tubercles or granules, each tipped with a hair; legs pale, front tibiæ with three dark dots above. Wings hyaline; venation pale, sometimes dotted with brown, and some cross-veins wholly brown or margined with brown, several of these spots near cubitus; stigma whitish, with dark at base; between subcosta and radius about six dark spots touching the veins, the last one paler, above these the costal cross-veins are brownish, and behind them there are faint brownish streaks across the wing; outer margin with some dark dots; at end of basal third on the hind margin is a brown tubercle or pupilla not one-half as long as in S. tuberculatus, and wholly dark. Hind wings with faint spots between subcosta and radius, the stigma, and some dots along outer margin brown. In fore wings there are two medio-cubital cross-veins before the median fork; between cubitus and its fork are fourteen to sixteen cross-veins; about fifteen cross-veins between radius and radial sector; radial sector with ten to twelve branches; first anal with six or seven branches to margin; in hind wings the base of median fork has the usual appendiculate veinlet.

Length of fore wing $q 17$ to $19 \mathrm{~mm}$., width 6.5 to $7.5 \mathrm{~mm}$.

Length of fore wing of $20 \mathrm{~mm}$., width $7 \mathrm{~mm}$.

Females from Kandy, Ceylon, May (E. E. Green).

Male from Ceylon (Nietner) Hagen Coll. 
In both sexes the fork of the median is only a little before the first fork of the radial sector, not as far as Petersen figures; but I doubt that there are two species closely allied on Ceylon. The male has the pronotum striped and lines on subcosta and radius and between as Petersen describes.

\section{SERICOSTOMATIDE}

Goera tagalica sp. nov.

Fig. 2.

\& Face with a crest of stiff hairs inward of each eye, yellowish at base, brown beyond; basal joint of antenna with yellow hair, but brown hairs near base below, rest of antenna brown, faintly annulate with pale; vertex with dense erect yellow hair; palpi black-haired; thorax with long, erect yellow hair in middle and in front; abdomen dull brown above, more yellowish beneath; front legs mostly dark, others yellowish, the femora more or less brownish, spurs black. Fore wings densely clothed with golden hair, outer fringe black or brown, some black hairs along the veins, bare spot conspicuous; hind wings dark, with nearly black hair and fringes.

Basal joint of antenna long, plainly longer than in G. conclusa. In fore wing the first fork goes fully one-half way back on the discal cell, forks two and three equal, the bare space at thyridium rather larger than in G. conclusa, about as in G. octospina. In hind wing fork one is only equal to fork three, very much shorter than fork two; fork five is but little wider and scarcely longer than fork three. The last ventral segment has a very short, blunt, median spine, and a tiny spine each side of it.

Expanse $17 \mathrm{~mm}$.

From Mt. Makeling, Luzon (Baker).

Differs at once from the two species known from the Philippines by the short fork one of hind wings. 
Goerinella minor sp. nov.

Fig. 6 .

Palpi pale yellowish, last joint of maxillary palpi white; basal joint of antennæ nearly black; vertex and thorax with brown hair. Legs pale; abdomen brown above, yellowish below, male genitalia very large, lower appendages three jointed, the second joint very large, superior appendages long, slender, up-pointed at tip. Wings short and broad, venation similar to G. piscina, but the end of thyridial cell is farther out, plainly beyond base of the discal cell. Scales of fore wing golden to brown, on the costa dense and dark brown; hind wing fumose, costal area hairy, the posterior fringes very long.

Expanse $10 \mathrm{~mm}$.

From Mt. Makeling, Luzon (Baker).

\section{Anisocentropus bellus sp. nov.}

Fig. 8

Head, palpi, and first and second joints of the antennæ yellow, with yellow hair, rest of antennæ black, the tips of joints marked with white; thorax yellow, with yellowish hair; abdomen dark brown above, yellowish below; femora yellowish, tibiæ and tarsi brownish, hind tibia and basitarsus with long brown hair. Basal half of fore wings pale brown, with yellowish hair, beyond clothed with black hair, with a curved band of bluish or lavender scales nearly across before tip, then along outer margin, and bending up to about the middle of the pale base; in the enclosed area is another patch of these lavender iridescent scales, with two fingers reaching toward tip of wing; the black marginal fringe is interrupted with tawny spots; hind wings brown, darker at tips. The front tibiæ and tarsi are faintly curved. The wings are more elongate than in 
A. magnificus or $A$. illustris, and the venation is not very distinct, but appears much like those species.

Expanse $24 \mathrm{~mm}$.

From Mt. Makeling, Luzon (Baker).

\section{HYDROPSYCHIDEE}

Macronema caliptera sp. nov.

Fig. 9.

Head and palpi bright yellowish, about four basal joints of antennæ also, then several joints brown to black, then about three joints white, beyond brown, at first white annulate, but toward tip wholly brown. Thorax and pleura black, abdomen dark brown; front femora and tarsi pale, tibiæ brown, mid and hind femora dark, mid femur paler at tip, hind tibia dark brown, mid tibia pale, dark at tip, both tarsi pale on base, dark toward tip. Wings dark brown, much broken with pale, especially toward base, at apical third a nearly complete curved pale band, divided by hardly more than a line, a little before this is a pale band three-fourths way across, on hind margin a little before this is a small pale spot, basal part pale, longitudinally divided by a brown streak, and the hind margin dark, gradually fading within; on costal base is a yellow spot, followed by a black spot, which is extended obliquely into the pale; the two median dark bands have golden scales through their middle, not reaching hind border. Hind wings dark, tip almost black, just before tip on costal margin is a pale spot. The venation is similar to that of $M$. radiatum and $M$. opulentum with the median cell broad and truncate at base.

Expanse $20 \mathrm{~mm}$.

From Mt. Makeling, Luzon (Baker). 
Dipseudopsis spectabilis sp. nov.

Fig. 1.

Head black, on vertex behind and near eyes yellowish; basal joint of antennæ yellowish, beyond black; palpi black; pronotum and rest of thorax black; abdomen black above, pale beneath; legs and spurs pale, coxæ dark. Fore wings dark brown with several large pale areas, mostly yellowish, but one beyond anastomosis more hyaline; an oblique spot from basal hind margin and an elongate spot in front of it, a large spot on hind margin, mostly before arculus, and reaching up to medius, a smaller triangular spot above base of discal cell, an elongate spot in discal cell, and one in the cell behind it; behind the anastomosis two elongate streaks, one in area behind fork two, and other over most of fork four and some in cell behind, these streaks broadly connected at base, and neither reaching the margin. Hind wings pale brown; fork one in fore wing very short, fork three with a pedicel nearly one-half of its length; in hind wing fork two reaches back in a point to the discal cell; and the cross-vein from basal part of median cell reaches extreme base of fork five. The inner spur of hind tibia ends in three points, the outer one much the longer and stouter, the middle one quite short.

Expanse $22 \mathrm{~mm}$.

From Sandakan, Borneo, C. F. Baker.

RHYACOPHILIDEE

Rhyacophila carletoni sp. nov.

Fig. 7.

Yellowish; head and thorax with mostly pale yellowish hair; antennæ pale, scarcely annulate with dark; palpi rather long and very slender. Legs pale, the tibiæ and part of tarsi darker, spurs pale; abdomen dark above, pale beneath. Fore wings pale, with many brown spots, mostly 
small and scattered, a large one over base, a prominent oblique one over middle of anal area, another, smaller, above the end of anal vein, several more or less connected spots near stigma, outer margin alternately brown and pale; hind wings scarcely infumate. In fore wings fork one barely longer than two, fork three long, about four times as long as pedicel, the connecting veinlet out on fork two, fork four as far back as fork two, and fork five fully as far back as base of discal cell. In hind wings forks one and two equal, fork three fully four times as long as its pedicel.

Expanse $30 \mathrm{~mm}$.

From Kooloo, North India (Carleton coll.).

Explanation of Plate 5.

Fig. 1. Dipseudopsis spectabilis, fore wing.

Fig. 2. Goera tagalica, tip of abdomen, and spines of last ventral segment.

Fig. 3. Ectopsocus xthiops bakeri, fore wing.

Fig. 4. Eophanes formosa, prothorax and head.

Fig. 5. Madrasta handlirschi, venation at apex of hind wing.

Fig. 6. Goerinella minor, genitalia side, and lower appendage from below.

Fig. 7. Rhyacophila carletoni, genitalia side.

Fig. 8. Anisocentropus bellus, fore wing.

Fig. 9. Macronema caliptera, fore wing. 

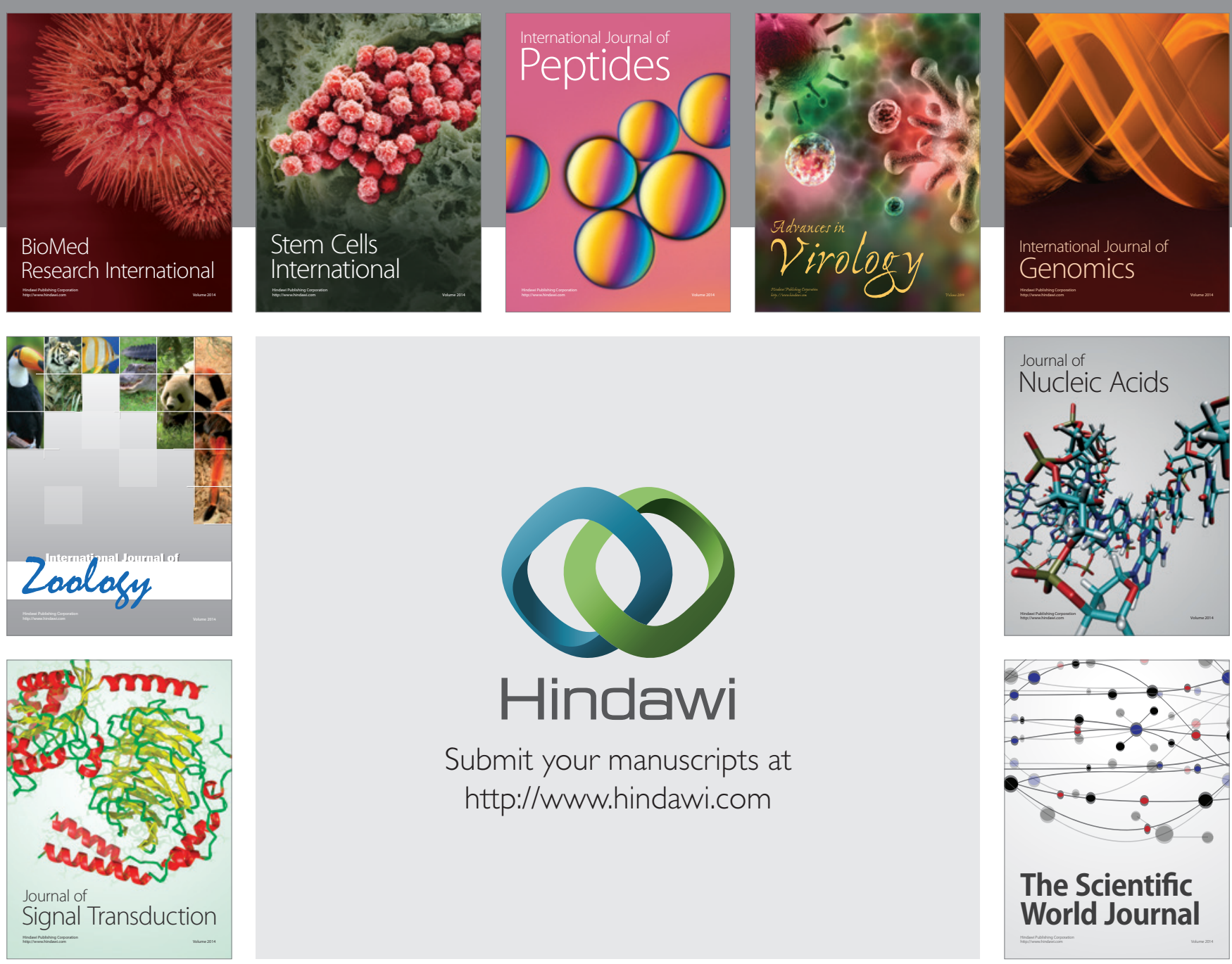

Submit your manuscripts at

http://www.hindawi.com
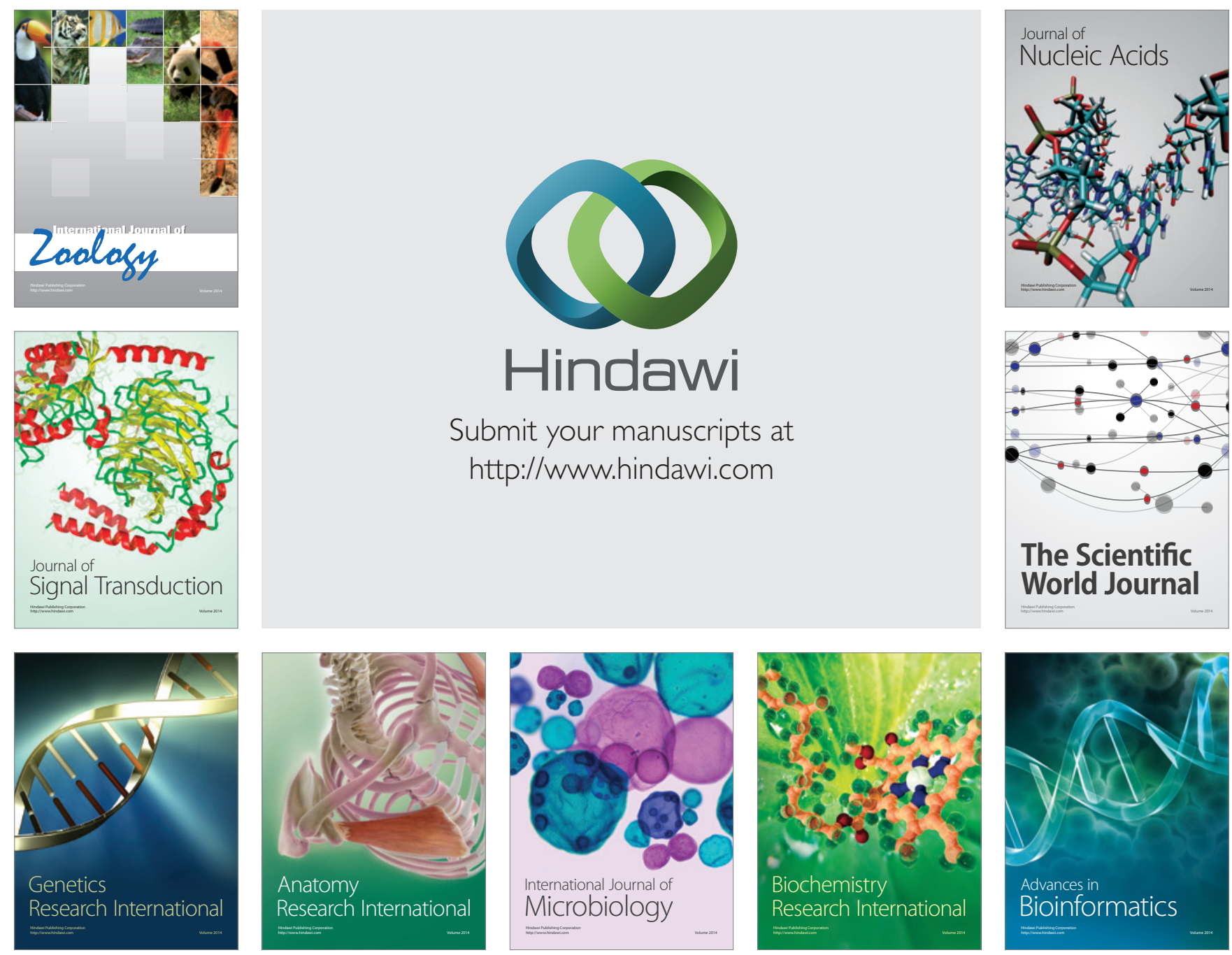

The Scientific World Journal
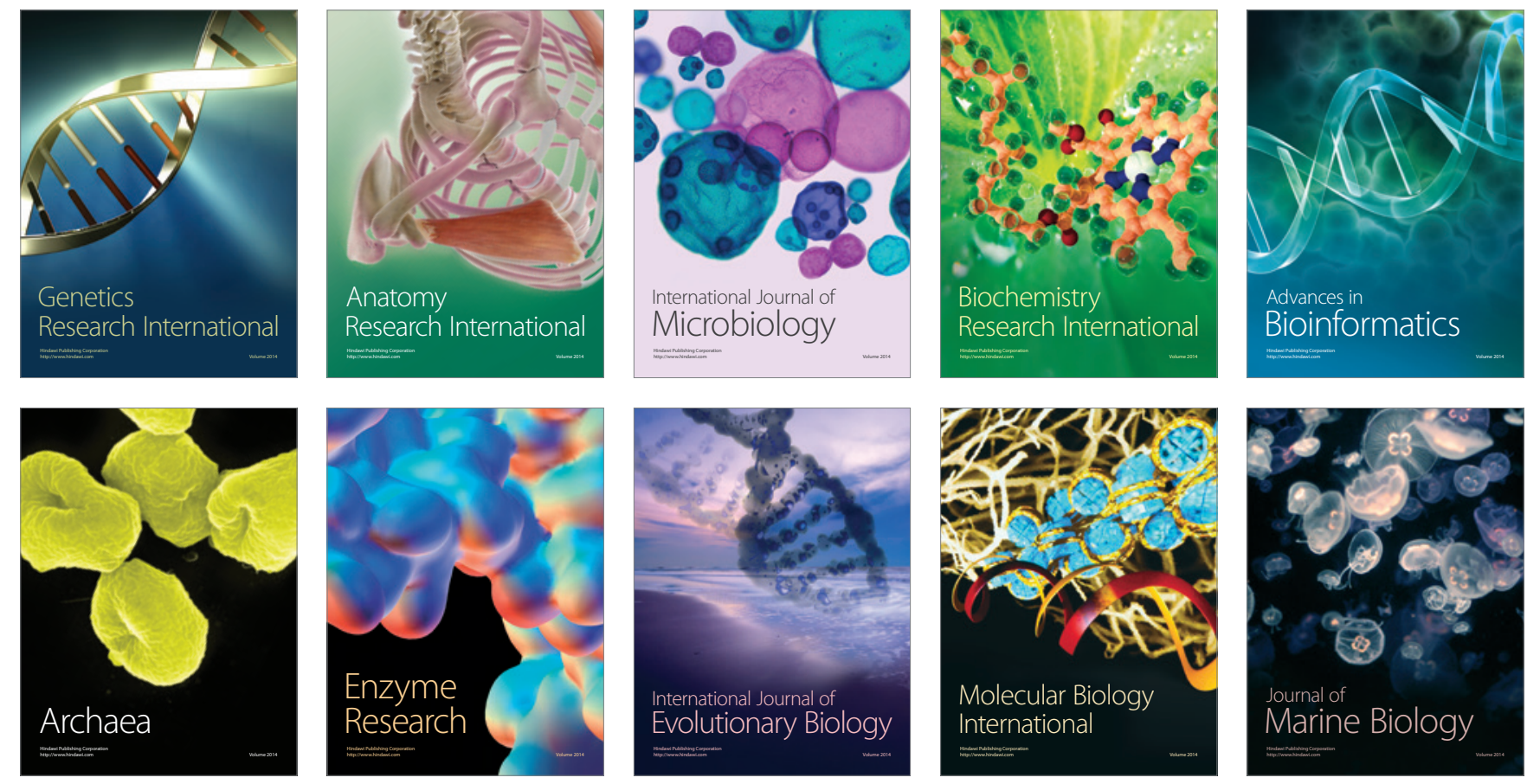